\title{
扁桃疾患における自律神経の関与に関する研究
}

一自律神経機能検査による検討一

$$
\text { 上景之 }
$$

\section{Various Tonsillar Diseases and Sympathetic Nerves}

\author{
Kageyuki Kozuki \\ (Kansai Medical University)
}

To clarify the function of the autonomic nervous system in patients with various tonsillar diseases, the microvibration $(\mathrm{MV})$ pattern and R-R interval of ECG were studied in these patients at rest and after tonsillectomy.

$\mathrm{R}-\mathrm{R}$ interval was below normal and MV frequency was abnormal in those with habitual tonsillitis or focal infection.

After tonsillectomy, the $\mathrm{R}-\mathrm{R}$ interval was significantly decreased in those with habitual tonsillitis or focal infection, compared with those with simple hypertrophic tonsil.

The MV pattern showed a significant increase in the sympathetic nerve activity after tonsillectomy in those focal infection, compared with those with habitual tonsillitis or simple hypertrophic tonsil.

Key words: tonsillitis, R-R intervals in ECG, microvibration

\section{緒言}

従来より扁桃と自律神経との関係は解剖学的 にも機能的にも密接であるとされている。すすな わち，口蓋扁桃の基底部に形成される扁桃神経 叢や扁桃組織内に分布する自律神経終末構成沶 よび動脈分布は扁桃の機能とくに免疫機能に関 与する部位に一致しているとされている1 ${ }^{1}$.ま た自律神経失調症状を有する慢性扁桃炎患者が 扁桃摘出術（以下，扁摘之略記）により症状の 改善が見られる事 ${ }^{2)}$, や病巣感染症や二次疾患 の成立機序および局麻による扁摘時のショック に Reilly 現象が密に関連している事 ${ }^{3)}$ なども 知られている。今回, 自律神経機能検査法とし
て心電図 $\mathrm{R}-\mathrm{R}$ 間隔の 変動 係数 (以下 $\mathrm{CV}$ 值之 略記）およびマイクロバイブレーション（以下 MV と略記）を指標として用い，扁桃疾患患者 の持つ自律神経疾患に対する素因，ならびに扁 摘による影響について検討を行ない，若干の考 察を加えて報告する．

\section{対象および方法}

対象症例は年 4 回以上の扁桃炎を繰り返す習 慣性扁桃炎44例, 病巣扁桃亡考えられる28症例 （腎炎 7 例，慢性 関節リウマチ 3 例，掌蹠膿疱 症13例, 微熱 5 例), 扁桃炎の既往の無い III 度肥 大を示す単純性扁桃肥大 13 症例, そして扁桃疾 患を持たない健常人13例（コントロール）の計 
96例であり，その男女比，年齢構成は表 1 亿示 した. CV 值の測定は景山4) の方法に従って行 った。すなわち被験者を約 10 分間以上安静仰臥 位に保ち, 安静呼吸状態における100心拍の RR間隔をオートノミック R-100（MEC 社製） を用いて測定した. R-R 間隔平均值 (Mean) および標準偏差 $(\mathrm{SD})$ から変動係数 (Coefficient of Variation：CV) を算出した. すなわち $\mathrm{CV}$ $=\mathrm{SD} /$ Mean $\times 100$ より各症例の $\mathrm{CV}$ 值を得た.

$\mathrm{MV}$ の測定は黒木5) の方法に従って行った. 室温を $23 \sim 25^{\circ} \mathrm{C}$ に保ったシールドルーム内で 被験者を安静仰臥位に 5 分間以上保った後, 利 き腕と反対側の手掌拇指球に日本光電社製の圧 電型ピックアップをセロテープで固定し，乙れ を脳波用増幅器に 接続し, $\mathrm{MV}$ の周波数分析 用に脳波周波数分析装置（三栄測器製）を用い た. $\mathrm{MV}$ 測定前の 2 日間はすべての薬物を中止 した. MV 周波数は10秒単位で $\theta(5.5 \sim 7.5 \mathrm{~Hz})$, $\alpha_{1}(7.5 \sim 8.5 \mathrm{~Hz}), \alpha_{2}(8.5 \sim 9.5 \mathrm{~Hz}), \alpha_{3}(9.5 \sim$ $10.5 \mathrm{~Hz}), \alpha_{4}(10.5 \sim 13 \mathrm{~Hz}), \beta(13 \sim 20 \mathrm{~Hz})$ の 6 周波数帯域に分析した. 分析された波型は下 記の式より各帯域の出現率 (energy \%) で表わ される，例えば $\theta$ 波については

$$
(\mathrm{E} \theta) \%=\frac{(\mathrm{A} \theta)^{2}}{(\mathrm{~A} \theta)^{2}+\left(\mathrm{A} \alpha_{1}\right)^{2}+\cdots+(\mathrm{A} \beta)^{2}} \times 100
$$
となる。

*ただし $\mathrm{A} \theta, \mathrm{A} \alpha_{1} \cdots \mathrm{A} \beta$ は各々 $\theta, \alpha_{1}, \cdots \beta$

表 1 対象症例の疾患別分類と男女比

1. 習慣性扁桃炎 44例

2. 病巣扁桃と考えられる症例
a. 腎 炎
b．慢性関節リウマチ
c. 掌蹠膿疮症
d. 微 熱

3. 単純性扁桃肥大

11

4. コントロール

13

\begin{tabular}{|c|c|c|c|c|}
\hline \multicolumn{5}{|c|}{ 計 96例 } \\
\hline 性別年齢 & $5 \sim 20$ & $21 \sim 40$ & $41 \sim 60$ & 計 \\
\hline 男 & 33 & 17 & 10 & 60 \\
\hline 女 & 13 & 16 & 7 & 36 \\
\hline
\end{tabular}

の10秒間の成分（振幅）として表わされる。

この周波数分析を用い表 $2^{6)}$ の基準で対象を $\mathrm{N}$ 型 (正常型)， $\mathrm{S}$ 型 (交感神経緊張型)， $\mathrm{F}$ 型 (副交感神経緊張型)，I 型 (全自律神経緊張型) の 4 型に分類した。 このうち， $\mathrm{N}$ 型は自律神経 機能正常で， $\mathrm{S}$ 型， $\mathrm{F}$ 型， I 型の 3 型は異常と 考えられる。

$\mathrm{CV}$ 值及び $\mathrm{MV}$ の測定を各症例毎に術前 3 日 及び術後 5 〜 6 日の 2 時期を選んで施行した. 尚，習慣性扁桃炎44例，病巣扁桃之考元られる 症例28例，単純性扁桃肥大11例，計83例につい ては全身麻酔下に扁桃摘出術が施行された。

\section{結果}

$\mathrm{CV}$ 值は一般に高年齢者程低值を示すので， 各種扁桃疾患を 5 〜 20才，21〜 40才，41〜 60才 と各年代別に分類してみると，5～20才では単 純性扁桃肥大 $7.31 \pm 0.77(\mathrm{n}=10)$ 飞比して習

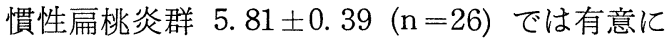
低值を示した．検定はスチューデント $\mathrm{t}$ 検定を 用い， $\mathrm{p}<0.05$ を有意差ありとした。 その他の 年齢層に拈いては各扁桃疾患間に CV 值は有 意の差を認めなかった。コントロールと扁桃疾 患との間にも各年代別に見て有意差は無かった (表 3 ).

次に景山4) の報告した健常者の CV 值より 小さい值を示した場合，副交感神経機能障害を 示していると考えられるので，その症例の割 合を各年代別，各種扁桃疾患別に分類してみる と，21４0才では習慣性扁桃炎群（80\%）に多

表 2 マイクロバイブレーション (MV) の周波数 分析による判定基準

(九大式分類 竹内 弘 $: 1980^{6)}$ を改変)

$\mathrm{N}$ 型 (正常型) : $\alpha$ 波が最も多いもので， $\theta$ 波の出 現率が30\%以下， $\alpha_{1}$ 波の出現率が35\%以下， $\beta$ 波の出現率か333\%以下を示すすの.

$\mathrm{S}$ 型 (交感神経緊張型) $: \theta$ 波が多いもので, $\theta$ 波 の出現率が30\%以上，あるいは $\alpha_{1}$ 波の出現 率が35\%以上を示すもの.

$\mathrm{F}$ 型 (副交感神経緊張型): $\beta$ 波が多いむので, $\beta$ 波の出現率が30\%以上を示すもの.

I 型 (全自律神経緊張型) : 不規則なパターンを 示し， $\theta$ 波（または $\alpha_{1}$ 波）および $\beta$ 波の出現 率がともに20\%以上を示すもの. 
く，5２0才では病巣扁桃と考えられる症例群 （71.4\%）に多かった（表 4). 扁摘前後の CV 値を比較するための指標として扁摘後の CV 值 $\left(\mathrm{CV}_{2}\right)$ を扁摘前の $\mathrm{CV}$ 值 $\left(\mathrm{CV}_{1}\right)$ で除して 100を乗じたもの (以下 CV 比と略記. CV 比 $\left.=\mathrm{CV}_{2} / \mathrm{CV}_{1} \times 100\right)$ を用いた ${ }^{7)} . \mathrm{CV}_{2}$ 值が增加
すれば CV 比は100より増加する。扁摘前後で $\mathrm{CV}$ 比を見ると, 習慣性扁桃炎群の CV 比は $105 \pm 8(\mathrm{n}=44)$, 病巣扁桃と考えられる群では $104 \pm 11(\mathrm{n}=28)$ となり, 単純性扁桃肥大群の $\mathrm{CV}$ 比, $120 \pm 20(\mathrm{n}=11)$ をコントロールと考 えると各々 $\mathrm{p}<0.05$ となり有意差ありと考えら

表 3 各種扁桃疾患におりる $\mathrm{CV}_{\mathrm{R}-\mathrm{R}}$ 值

\begin{tabular}{|c|c|c|c|}
\hline 年齢 & $5 \sim 20 才$ & $21 \sim 40 才$ & 41 ６0才 \\
\hline $\begin{array}{l}\text { 習慣性扁桃炎 } \\
\text { 病坚扁桃之考えられる症例 } \\
\text { b. 炎慢性関節リウマチ } \\
\text { c. 掌蹠膿疱症 } \\
\text { d. 微 熱 } \\
\text { 単純性扁桃肥大 }\end{array}$ & $\begin{array}{l}5.81 \pm 0.39 *(26) \\
7.52 \pm 1.89(5) \\
7.0(2) \\
7.31 \pm 0.77(10)\end{array}$ & $\begin{array}{l}4.47 \pm 0.41(15) \\
3.76(1) \\
6.08 \pm 1.30(6) \\
5.3(2)\end{array}$ & $\begin{array}{l}3.67 \pm 0.45(3)^{(\mathrm{n})} \\
1.15(1) \\
3.42 \pm 0.52(3) \\
3.87 \pm 1.07(7) \\
1.53(1) \\
3.50(1)\end{array}$ \\
\hline \multicolumn{4}{|c|}{$*(\mathrm{P}<0.05)$} \\
\hline コントロール & $6.09 \pm 2.38(3)$ & $5.02 \pm 1.95(9)$ & $3.32(1)$ \\
\hline
\end{tabular}

表 $4 \mathrm{CV}$ 値が正常以下の占める割合

\begin{tabular}{l|c|c|c}
\hline 年齢 & $5 \sim 20$ 才 & $21 \sim 40$ 才 & $41 \sim 60$ 才 \\
\hline \hline 習慣性扁桃炎 & $15 / 26(57.6)$ & $12 / 15(80.0)$ & $0 / 3(0.0)$ \\
病巣扁桃と考えられる症例 & $5 / 7(71.4)$ & $6 / 9(66.6)$ & $8 / 12(66.6)$ \\
単純性扁桃肥大 & $2 / 10(20.0)$ & $0 / 0(0.0)$ & $0 / 1(0.0)$ \\
コントロール & $2 / 3(66.6)$ & $5 / 9(55.6)$ & $0 / 1(0.0)$
\end{tabular}

表 5 各種扁桃疾患とマイクロバイブレーション $(\mathrm{MV})$ 各型との相関関係

\begin{tabular}{|c|c|c|c|c|c|c|}
\hline & $\mathrm{S}$ & $\mathrm{N}$ & $\mathrm{F}$ & I & 計 & MV 異常率 \\
\hline \multicolumn{7}{|l|}{ 病巣扁桃と考えられる症例 } \\
\hline ( a . 腎 炎 & 0 & 3 & 4 & 0 & 7 & \multirow{4}{*}{$14 / 28=50$} \\
\hline b. 慢性関節リウマチ & 1 & 1 & 1 & 0 & 3 & \\
\hline c．掌蹠膿疱症 & 0 & 7 & 6 & 0 & 13 & \\
\hline $\mathrm{d}_{\mathrm{d} . \text { 微 熱 }}$ & 0 & 3 & 2 & 0 & 5 & \\
\hline 単純性扁桃肥大 & 0 & 7 & 4 & 0 & 11 & $4 / 11=36.4$ \\
\hline \multirow[t]{2}{*}{ コントロール } & 2 & 9 & 2 & 0 & 13 & $4 / 13=30.1$ \\
\hline & 5 & 54 & 36 & 1 & \multicolumn{2}{|c|}{ 96例 } \\
\hline
\end{tabular}


れた（図 1)。 また単純性扁桃肥大群で CV 比 が大きくなったのは術後 $\mathrm{CV}_{2}$ 值が増加する傾 向を示したためである.

MVについては術前安静時の測定結果を各種 扁桃疾患及びコントロールについて $\mathrm{S}, \mathrm{N}, \mathrm{F}, \mathrm{I}$ 型と分類し表 5 に示した. MV 異常率は病巣扁 桃之考えられる症例 $(50.0 \%)$ ，習慣性扁桃炎 $(47.7 \%)$, 単純性扁桃肥大 (36.4\%), コントロ ール (30.1\%) の順に高い. 異常型の中では各 疾患群について F 型の出現率が高かった.

次に扁摘前後でのパターン変化を見るために

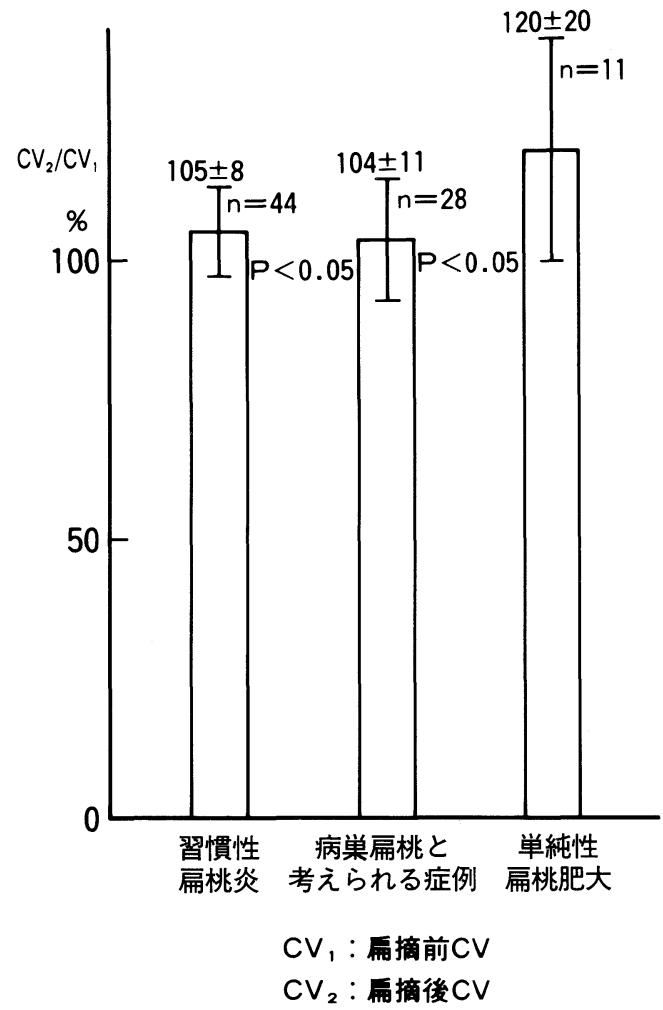

図 1 扁桃摘出術前後の $\mathrm{CV}$ 值の変化 (CV 比)

表 6 扁桃摘出術前後でのマイクロバイブレーシ ヨン $(\mathrm{MV})$ 各型の変化

\begin{tabular}{c|c|c|c}
\hline \hline & $\begin{array}{c}\text { 交感神経 } \\
\text { 張 群 }\end{array}$ & 不 変 群 & $\begin{array}{c}\text { 副交感神 } \\
\text { 経緊張群 }\end{array}$ \\
\hline 習慣性扁桃炎 & 19 & 21 & 4 \\
病 宩 感 染 & $18^{*}$ & 9 & 1 \\
単純性扁桃肥大 & 3 & 7 & 1 \\
& & & $* \mathrm{P}<0.01$
\end{tabular}

石部ら ${ }^{7)}$ の方法により各型の変化で 3 群に分類 した.すなわち $\mathrm{F}$ 型より $\mathrm{N}$ 型， $\mathrm{F}$ 型より $\mathrm{S}$ 型, $\mathrm{N}$ 型より $\mathrm{S}$ 型へと交感神経系の緊張の亢進した 群を交感神経緊張群，MV の変化の見られなか ったものを不変群， $\mathrm{N}$ 型より $\mathrm{F}$ 型， $\mathrm{S}$ 型より $\mathrm{N}$ 型， $\mathrm{N}$ 型より $\mathrm{F}$ 型へと副交感神経系の緊張の立 進した群を副交感神経緊張群とした。扁摘前後 での MVの変化を見ると各疾患群において扁 摘後交感神経緊張群となる症例が多かったがと くに病巣感染群ではその变化は著明であった $(\mathrm{p}<0.01)$ (表 6$)$. 有意差検定は病巣感染を持 つ群と持たない群，交感神経緊張群とその他の 群で分けてカイ二乗検定を行なった.

\section{考按}

1973年 Wheeler $ら^{8)}$ の報告や景山ら ${ }^{4)}$ の報 告以来，心電図 $\mathrm{R}-\mathrm{R}$ 間隔の変動を用いた自律 神経機能検査法が広く普及しており，筆者もと の手法を用いた。すなわち心電図上の $\mathrm{R}-\mathrm{R}$ 間 隔の変動は，洞調律の変化を反映し，乙の R-R 間隔は硫酸アトロピンの投与により迷走神経を 遮断すると消失する事から，副交感神経支配と 密接な関係をむっていると考えられる．また， 一般に CV 值は糖尿病性神経障害，加齢など で減少し，主に迷走神経機能，副交感神経機能 の低下をみているが，同時に交感神経機能六 進む反映しているとされている．MV は，1944 年 Rohracher ${ }^{10)}$ によりはじめて観察されたも のである. 生理的に存在する人体表面の目に見 えない細かい振動で，温血動物にのみあり，冷 血動物には見られないととから，体温調節と関 係のある自律神経の活動であろうとされてい る. MV の発生機序は，不明の点もあるが，現 在では筋性振動成分のほかに，心弾図性振動成 分が関係しているとされており，安静無負荷時 の自律神経機能状態を循環系, 筋肉系を指標之 してみていると考えられている5．MV パター ンとメコリール試験やアシュネル試験とは良く 対応するとされて抢り，黒木 ${ }^{5)}$ によると各種疾 患での自律神経機能状態は，例えば本態性高血 圧症や，胃潰瘍では MV 異常率が高くその中 
$\mathrm{S}$ 型の占める比率が高く，それに比して過敏性 大腸症候群では MV 異常率は低く，そのうち $\mathrm{F}$ 型の占める割合が多いと報告している.

緒言でも述べたごとく扁桃と自律神経との関 係については，従来より多くの関心が集められ ている．今回，筆者は外来で手軽に行える非侵 襲的かつ客観的で再現性のある自律神経検査法 として CV 值抒よび MV という手法を用いて, 各種扁桃疾患症例の安静時の検討加ら自律神経 的素因について，次いで扁摘による影響につい て考察を試みた。

形浦ら ${ }^{11}$ は各種扁桃疾患群における $\mathrm{CV}$ 值 を測定し，高齢者程低值を示す傾向は認められ るが，病巣性扁桃炎患者において有意な変化が 認められず，また扁摘の効果との間にも有意な 相関は認められなかったと報告している，筆者 の成績も総体的には形浦の報告と同様の結果で あったが，個々の成績たとえば 5 ～20才の年齢 群では習慣性扁桃炎群は単純性扁桃肥大群に比 して有意に CV 值が小さいという結果を得, こ れは扁桃炎が習慣性になる症例群では副交感神 経活動の低下または交感神経系の緊張状態が基 礎にあるのではと推測された (表 3 ). 今回の成

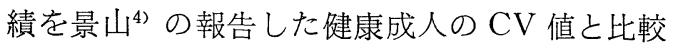
した場合，21〜40才の習慣性扁桃炎群や 5 ～20 才の病巣扁桃と考えられる症候群には同年代の コントロールや扁桃肥大に比して CV 低值を 示し迷走神経活動低下の素因を示唆すると考え られた (表 4). 疾患は異なるが咽喉頭異常感症 症例の自律神経機能を $\mathrm{CV}$ 值を用いて評価し た報告によると，前山ら ${ }^{12)}$ は，咽喉頭異常感症 の半数以上に自律神経異常が存在すると推定 し, 安静時の CV 值が正常, 小であるもの, 大 であるものがそれぞれ89\%，26\%，15\%であっ たとしている. 中西ら ${ }^{13)}$ は全症例の $24.7 \%$ にお いて CV 值が正常以下の副交感神経機能障害 を認め，また 30 才代，40才代でその比率が高 く，精神的，肉体的ストレスによる自律神経系 への関与が示唆されるとしており，扁桃疾患と 咽喉頭異常感症との病態の背景に自律神経系異
常の共通項を示唆すると考えられ興味深い.

各種扁桃疾患患者におりる安静時 $\mathrm{MV}$ パタ 一ンを検討すると, 病巣扁桃と考えられる症例 や習慣性扁桃炎では， F 型（副交感神経緊張 型）の占める割合が多く, CV 值の成績と矛盾 する様に思われた（表5). しかしてれは MV による自律神経機能検査が，主として循環系お よび筋肉系の機能状態を反映しているので, 安 静無負荷時には CV との相関は少ないのでは ないかと考えた. しかし MV 異常率が病巣扁 桃や習慣性扁桃炎群に比較的多く見られる事は やはり注目すべき結果であると考えられた.

扁摘前後の $\mathrm{CV}_{2}$ 值は習慣性扁桃炎群及び病 巣扁桃と考えられる群ではとくに $\mathrm{CV}_{2}$ 值に変 化が無く, 単純性扁桃肥大群のみが術後 $\mathrm{CV}_{2}$ 值の上昇を示した。習慣性扁桃炎群及び病巣扁 桃と考えられる症候群は単純性扁桃肥大群に比 $し て \mathrm{CV}_{2}$ 值は相対的に小さく有意差あり $(\mathrm{p}<$ 0.05)とした（図 1).

扁摘前後の $\mathrm{MV}$ パターンの変化は病巣感染 と考えられる群では交感神経系の緊張元進へと 変化した事を示している. 安静無負荷時では一 致しなかった $\mathrm{CV}$ 值と $\mathrm{MV}$ との関係が扁摘と いう刺激が全身に影響を及ぼした事により両者 の傾向が一致に向い，両者とも交感神経緊張型 になったと考えられた (表 6 ). 筆者 ${ }^{14)}$ は先に 局所扁桃組織中のノルエピネフリン (NE) 值が 高くなる事より習慣性扁桃炎や病巣扁桃での局 所の交感神経活動の交進を示唆したが上述した 様に今回 CV 值や MV を用いた全身の自律神 経機能検查でも扁桃疾患患者の素因には副交感 神経活動の低下もしくは交感神経活動の六進状 態が存在すると考えられた.

一般に交感神経系の緊張が方進すれば腎血流 量の低下や皮膚血流量の低下 ${ }^{15)}$ が起 こ 事が 知られており, 腎炎や掌蹠膿疮症等の病栄扁桃 の成立の一因子として影響を及ぼすと推測され る. 交感神経作用薬であるアドレナリン（エピ ネフリン) を注射すると, $\theta$ 波の出現率が増加 し MV のパターンが $\mathrm{S}$ 型（交感神経緊張型） 
へと変化する事 ${ }^{5)}$ や $\mathrm{CV}$ 值の低下 ${ }^{9)}$ が報告さ れており，今回の結果に扁摘や扁桃誘発その他 の刺激による血中アドレナリン(エピネフリン) の増加による影響も理論的には無視できない. しかし筆者 ${ }^{14)}$ が報告した如く扁桃組織中の $\mathrm{NE}$ 值は $10^{-9} \mathrm{~g}$ のオーダーであり血中 $\mathrm{NE}$ 值 は一般に $10^{-12} \mathrm{~g}$ のオーダーで測定されており， 局所神経由来の NE 值の果たす影響は全身の それと比較できない位大きいあのであろうと考 えられた。

鈴木 ${ }^{3)}$ は咽頭部の手術時とくに扁桃への刺激 は過剩刺激に成り易く, 全身諸臟器および諸器 官に，主として自律神経系を介して血管系の病 変，即ちレーリ一氏現象を起とすすのと考え， その急激なる刺激はショックとなり，緩慢なる 慢性炎症は病巣感染の一因子となり得るとして いる，耳鼻科手術の中で扁摘の占める頻度は高 く, 扁摘時のショックを考える際, 習慣性扁桃 炎や病巣扁桃に対しては局麻ではなく全麻下に 手術を行なうのが理想であろう。あし局麻下に 行なう時は術前安静無負荷時に CV 值低下や MV 異常率より患者の自律神経状態を知って おく事はショック予防の観点からあ有益な検査 であるとあ考えられる．また扁摘後に喘息や鼻 アレルギーが出現したり悪化する事が報告 ${ }^{16) 173}$ されており，乙れは扁摘により代償性に副交感 神経系の機能元進が起こるためと推測され，術 前に予測できれば手術時期を調節する事，つま りアレルギー性鼻炎の好発する季節を避けた り，喘息の根本治療が終了してから手術をする 等の工夫が可能となろう.

\section{結語}

扁桃疾患における交感神経の関与を知るため に, 安静無負荷時および扁摘前後での $\mathrm{CV}$ 值と MV とについて検討した。

習慣性扁桃炎や病巣扁桃の患者の自律神経素 因としては CV 值の低下より交感神経系の立 進が示唆され，咽喉頭異常感症との共通項が考 えられた. MV では MV 異常率が高く自律神 経系の乱れが示された。扁摘後は相対的な交感
神経系緊張亢進が起こることが $\mathrm{CV}$ 值の変動 $(\mathrm{CV}$ 比) により示唆され， $\mathrm{MV}$ のパターン変 化でみると, 病巣感染群に扔いて交感神経緊張 型へと変化している事が示された。乙れらの事 より，筆者 ${ }^{14)}$ が先に報告した扁桃局所での生化 学的な交感神経緊張状態と自律神経機能検査に よって得られた全身の交感神経系緊張とは，よ く相関していると考えられた.

稿を終えるにあたり，御指導ならびに御校閲を賜り ました恩師，熊澤忠躬教授に深甚なる謝意を表しま す。また直接の御指導，御助言を頂きました山下敏夫 助教授に深謝いたします。本研究での技術面での御指 導, 御助言を頂きました石部 司非常勤講師に深謝い たします。

なお，本論文の要旨の一部は第48回耳鼻咽喉科臨床 学会, 第26回日本扁桃研究会総会および第 1 回国際扁 桃シンポジウムの中で発表された.

本研究の一部は文部省科学研究費 (一般研究 B 課 題番号58480353）の補助を受けた.

\section{文献}

1) 浅野 毅：扁桃の免疫に関する研究一七ト口蓋扁 桃の自律神経分布について一。 日扁桃誌 18 ： 169 185, 1979.

2 ）野坂保次: 扁桃の基礎之臨床. 237頁, 日本医事 新報社, 東京, 1977 .

3) 鈴木安恒 : 耳鼻咽喉科領域におけるレーリ一氏現 象. 日耳鼻 $66: 1473 \sim 1475 ， 1965$.

4) 景山 茂: 心電図 $R-R$ 間隔の変動之自律神経 系一生理学的意義と糖尿病性自律神経障害への応 用一. 神経内科 $19: 119 \sim 126,1983$.

5）黒木かほる：Microvibration による自律神経機能 検查. 自律神経 $9: 163 \sim 176,1972$.

6) 竹内 弘: Microvibration (MV) を用いた自律神 経機能検査に関する臨床的研究. 日口外誌 126 ： 74 90, 1980.

7) 石部 司, 細田泰男, 堀 芳朗, 他: 扁桃誘発試 験之自律神経機能検查. 日扁桃誌 $26: 206$ 211, 1987.

8) Wheeler $\mathrm{T}$ and Watkins PJ : Cardiac denervation in diabetes. Dr Med J 4:584 586, 1973.

9 ) 持尾聰一郎 : 心電図 $R-R$ 間隔の変動之自律神経 
系一中枢神経疾患への応用を中心に一. 神経内科 $19: 127 \sim 132,1983$.

10) Rohracher $\mathrm{H}:$ Schwinguaogen im menschlichen Organismus. Anz d Phil -hist Klasse d Osterr. Akad d Wiss $18: 230 \sim 245,1946$.

11）形浦昭克 : 扁桃病巣感染症一発症機序の解明之臨 床への応用一. 第87回日耳鼻総会宿題報告, 1986 .

12) 前山忠嗣, 進 武幹, 渡辺 宏, 他: 咽喉頭異常 感症例の自律神経機能検查. 耳鼻臨床 $78: 2375$ $\sim 2382,1985$.

13）中西泰夫, 岩田重信, 八木沢幹夫 : 咽喉頭異 常 感症症例の自律神経機能. 日食 $37: 1 ; 1 \sim 7$, 1986.

14）上月景之：扁桃疾患における交感神経の関与に関 する研究一神経伝達物質による検討一. 耳鼻臨床
$80: 299 \sim 312,1987$.

15) Goodman A, Gilman, et al : Goodman and Gliman's The Pharmacological Basis of Therapeutics. pp 526 527, 7th Edition, Macmillion Publishing Company, London, 1985.

16）野坂保次：口蓋扁桃摘出後の遠隔成績. 日本医事 新報 $1951: 35,1957$.

17）池田美智子, 小名 愛, 和田 萃, 他 : 扁桃摘出 後の遠隔成績一アンケート調査による一. 日扁桃 誌 $22: 117 \sim 123,1983$.

$\left(\begin{array}{l}\text { 原稿採択 : 平成元年 } 2 \text { 月 } 13 \text { 日 急載 } \\ \text { 別刷請求先 : 上月景之 } \\ \text { T570 大阪府守口市文園町 } 1 \\ \text { 関西医科大学耳鼻咽喉科学教室 }\end{array}\right)$

